\title{
Economic growth and Indian
}

\section{wealth-income ratios in the long run: 1860-2018}

\author{
Rishabh Kumar* \\ University of Massachusetts \\ Boston
}

*Email: Rishabh.Kumar@umb.edu. I am grateful to Thomas Piketty, Xiao Jiang, JW Mason, Daniele Tavani, Suresh Naidu, Gurbachan Singh and Aaron Benanav for their suggestions and comments during various stages of my tryst with this research. I also thanks the participants of 2018 meetings of the Eastern Economics Association, World Economic History Congress, ACEGD 2019 at ISI Delhi, ECINEQ 2019 at Paris School of Economics and seminars at Columbia South Asia Institute and New School for The Social Research. I am especially grateful to Luis Bauluz and Gabriel Zucman for in-depth discussion regarding wealth-income ratios. All remaining errors are solely my own. 


\begin{abstract}
This paper presents new series on the evolution of wealth-income ratios in India. I construct a new macro-history dataset, covering the period 18602018 and containing historical series on national wealth and its components, national income, savings, investment and prices. These data show a gradual rise in India's national wealth-to-national income ratio $(\beta)$ since the midtwentieth century, with the main takeoff occurring since the 1980s. This recent rise in $\beta$ is concurrent with India's transition to a high-growth emerging economy, characterized by capital accumulation and growing importance of a modern sector. Prior to this period (1900-1980), the Indian economy struggled to hit growth rates over 1-2 percent per-capita and wealth-income ratios varied inversely with economic growth. At low growth rates, regardless of the level of development, wealth-income ratios are more sensitive to relative asset prices. On the basis of these findings, I propose a turning point in the relationship between $\beta$ and economic growth which explains the simultaneous rise of wealth-income ratios in both slow growth (rich) and high growth (emerging) economies since the late twentieth century.
\end{abstract}

\title{
JEL Classification: E10, D30, D31, N15, O11
}

Keywords: Wealth-Income Ratio, Economic growth, India, Inequality, Asset prices, Capital accumulation 


\section{Introduction}

This paper documents and analyzes findings from a new macro-historical dataset of wealth in India over the long run, covering 1860-2018. Over this period, the Indian economy underwent a radical transformation; from an agriculture dependent British colony until the mid twentieth century, to a planned independent economy for three decades (1950-1980). In the 1980s, after abandoning the mixed economy experiment, India's trajectory changed; economic growth took off to some of the highest rates seen in a major economy in recent decades (Lamba and Subramanian, 2020). Still, little is known about the evolution of Indian wealth and its metamorphosis over this period. Given the centrality of wealth accumulation to modern capitalist economies, this leaves a fairly big gap in knowledge not just in the Indian context, but also vis-a-vis our understanding of wealth in non-advanced economies over the long run.

To address this gap, my paper systematically combines historical estimates, official surveys and national accounts to construct series for national wealth, national income, saving rates, prices etc. From these data, I compute and decompose the evolution of wealth-income ratios for India. In the last decade, the literature on wealth-income ratios has gained prominence following the "comeback of wealth" hypothesis of Piketty and Zucman (2014). To the best of my knowledge, my paper is the first to construct wealth-income ratios for India, and for any developing country over such an extended period of time. I wish to be clear that my estimates are far from perfect, especially for the colonial period, but they mobilize the best sources at hand and are supplemented by related trends which support my findings. The data and its sources are fully documented and step-by-step recon- 
struction is shown in this paper's companion excel file.

My main series of interest throughout this paper is the ratio of national wealth to national income $(\beta=W / Y)$. Here, $\beta$ normalizes wealth by the level of national income, representing the years of national income accumulated as total wealth. For example, a wealth-income ratio of $\beta=500 \%$ implies that national wealth is worth five years of national income. Given that wealth tends to be more concentrated than income, and the possible divergence of asset and output prices, a rise in wealth-income ratios very often points to further concentration ${ }^{1}$ of wealth and income among the rich. Although economic theory normally presumes fixed shares of capital and labor income, an increase in wealth-income ratios at a given rate of return also raises the capital share, thus shifting the distribution of income in favor of capital owners.

The level and trend of Indian wealth-income ratios are especially relevant from an institutional perspective. In the well known Acemoglu-Johnson-Robinson (AJR) model (Acemoglu et al., 2002), the lack of early industrialization in previously wealthy societies is explained on the basis of extractive institutions which were reinforced by colonial rule. During the colonial period, property rights were coopted and secured by a small set of wealthy elites (landlords, local rulers) and surpluses were shared with the colonial administration. In the presence of such institutions, there was little incentive to undertake productive investments to in-

\footnotetext{
${ }^{1}$ There are obvious exceptions; for instance it might be the case that a public wealth fund is growing during a period of rising natural resource booms. Historically though, it is more often private wealth increasing faster than national income, and specifically, due to wealth accumulation at the top of the distribution. See Chancel et al. (2018)
} 
dustrialize or generate economic growth. Based on this model, one should assume wealth-income ratios were high in India during the colonial era, when wealth was concentrated but unproductive, and lower in the period after independence, following the abolition of undemocratic institutions and the onset of rapid economic growth.

The data suggest a different evolution of Indian wealth-income ratios in the long run. I find that Indian wealth-income ratios $(\beta)$ increased over the twentieth century, with the main takeoff coinciding with the onset of impressive per-capita income growth in the 1980 s. Prior to the 1950 s, economic growth was very low and wealth-income ratios were subject to large fluctuations: a 2 percent real rate of capital gains compounds wealth-income ratios quickly when economic growth is 0.5-1 percent, versus (say) 4-5 percent. Based on my findings, I argue that the long run shape of $\beta$ follows a U-shaped relationship with economic growth $(g)$. At low growth, asset prices become important drivers of excursions from trend. During sustained periods of high growth - present usually in emerging economies undergoing catch-up - capital accumulation intensifies, raising per-capita income and saving rates, as predicted by dual-sector growth models. This U-shaped relationship explains both inter-temporal trends in India, and helps understand the simultaneous rise of wealth-income ratios in low growth rich countries and emerging economies like India and China.

The rest of this paper is organized as follows. Section 2 discusses the literature on wealth-income ratios and estimations on Indian wealth before laying out concepts and data sources used in the construction of my data. Section 3 starts by giving a historical background and then presents the main results over time, 
explaining key trends using wealth decompositions. Section 4 analyzes the relationship between $\beta$ and $g$. Section 5 concludes. This paper is supplemented by an online appendix which expands on the data and methodology, as well as a supplementary dataset in excel format (IndiaWealthIncomeRatios.xlsx).

\section{Literature, concepts and data}

\subsection{Relation to literature on the historical evolution of wealth}

This paper contributes to a rich new literature on wealth-income ratios that emerged following Piketty and Zucman (2014). The standout pattern in Piketty and Zucman (2014) is the comeback, starting in the 1970s, of wealth-income ratios to nineteenth century ${ }^{2}$ levels. Notably, the countries analyzed in the long run - USA, Western Europe - were basically industrialized and wealthy by the start of the twentieth century. Secondly, European ratios were shaped in a big way by the capital destruction due to the two World Wars, as well as the democratization of wealth through pensions and the welfare state (Waldenström, 2021). The thrust of this analysis is that wealth-income ratios are subservient to their predicted values according to the Harrod-Domar-Solow steady state formula, $\beta=s / g$. As these economies matured into low growth, the effects of geopolitical and institutional shocks wore out and $\beta$ returned to (or even exceeded) past levels. Several new studies have focused on long run wealth-income ratios of specific countries; for instance Waldenström (2017) for Sweden, Madsen (2019) for the UK and Artola

\footnotetext{
${ }^{2}$ An important new update by Waldenström (2021) highlights that older values of wealthincome ratios may very well be inflated by old national income estimates. Despite these revisions, with a decline occurring in the mid twentieth century, the U-shaped evolution holds.
} 
et al. (2021) for Spain. In all the aforementioned economies, $\beta$ evolves $^{3}$ according to a U-shape, highlighting lower growth rates and war-related destruction in some form or the other (Spanish Civil War, World War II etc).

To generalize our theories about wealth and wealth-income ratios, we need to also take into account long run trajectories of today's developing economies. The nature of shocks and institutions in such countries are different - colonialism, socialist planning, industrial policy (or lack thereof) etc. Using recent releases of balance sheets, other authors have constructed country-specific series over the post-war period: Lee and Yoon (2017) for South Korea, Charalampidis (2018) for Greece, Piketty et al. (2017) for China, and Novokmet et al. (2018) for Russia. Strikingly, twenty first century wealth-income ratios have risen in all these countries, shedding doubt that low growth alone - especially accounting for China explains rising wealth-income ratios. Introducing India into the mix shows one possible path for an economy that is growing rapidly today, but where growth rates were in a lull for 80 percent of the twentieth century.

\subsection{Wealth-income ratios}

For unfamiliar readers, I quickly introduce the main concepts and framework to understand the subsequent content. A basic law of motion for wealth is given by the following equation:

$$
W_{t+n}=W_{t}+S_{t}+\delta_{t+n} W_{t}
$$

\footnotetext{
${ }^{3}$ For a summary of these revised data, see Waldenström (2021)
} 
According to Equation 1, wealth $(W)$ increases from its initial value due to volume based effects (savings, $S_{t}$ ) and price effects (capital gains, $\delta_{t+n} W_{t}$ ). In one good models, where the same good can be consumed or saved, $\delta_{t+n}$ equals zero and all wealth changes are due to savings, or some physical destruction of initial wealth. Obviously, asset prices are important in the real world where the one good models may be unrealistic; sustained price deviations can result from asymmetric economic shocks, real estate pressure or structural capitalization of monopoly rents.

From a macro-historical perspective, my key variable of interest is the wealthincome ratio: $\beta_{t}=W_{t} / Y_{t}$ where $Y$ is national income. The value of $\beta_{t}$ denotes the years of annual national incomes necessary to reproduce the stock of wealth. In a large class of general equilibrium models, $\beta$ converges to the ratio of saving rates $(s=S / Y)$ and economic growth $g$, i.e. $\beta_{t} \rightarrow \beta=s / g$ in the long run (Piketty and Zucman, 2014). This result is the same as the one good Harrod-Domar-Solow steady state, where $\beta$ represents the capital-output ratio. Therefore, for any given saving rates, a decline in economic growth ${ }^{4}$ predicts higher steady state wealthincome ratios. The fundamental logic of this framework is easy to visualize in plain language - accumulated wealth from the past will appear "large" in a low growth economy.

\footnotetext{
${ }^{4}$ As Piketty and Zucman (2014) mention, the inverse relationship between $\beta$ and $g$ also holds in models with endogenous savings
} 


\subsection{Multiplicative versus additive wealth equations}

Besides tracking the evolution of wealth-income ratios, I also use wealth decompositions to separate the role of volume and price effects in wealth accumulation, with special interest in their changing roles over time. Wealth can be decomposed using multiplicative or additive wealth equations.

In multiplicative models, wealth evolves according to $W_{t+1}=(1+q)\left(W_{t}+s Y_{t}\right)$. Normalizing both sides by $W_{t}$, the multiplicative equation can be restated as:

$$
\left(1+g_{w}\right)=(1+q)\left(1+g_{w s}\right)
$$

Where $1+q$ is the (real) capital gains factor, $1+g_{w}=\left(W_{t+1}\right) /\left(W_{t}\right)$ is the wealth growth factor and $1+g_{w s}$ is the volume driven wealth growth factor with $g_{w s}=s / \beta_{t}$. Equation 2 can be used to estimate capital gains as a residual, since data on income, savings and wealth are usually more easily available (and reliable) for historical periods.

The additive equation can be derived directly by cumulating savings and dividing Equation 1 by $Y_{t+n}$ to get:

$$
\beta_{t+n}=\underbrace{\frac{W_{t}}{Y_{t+n}}}_{\text {Initial wealth }}+\underbrace{\frac{S_{t, t+n}}{Y_{t+n}}}_{\text {Cumulated savings }}+\underbrace{\frac{\delta_{t+n} W_{t}}{Y_{t+n}}}_{\text {Cumulated capital gains }}
$$

Again, cumulated capital gains can be estimated as a residual in the additive equation. The other advantage here is that additive models allow for zero savings - in the long run, positive saving rates are essential to the multiplicative equation ${ }^{5}$

\footnotetext{
${ }^{5}$ At the steady state, with $q \neq 0, \beta^{*}=s(1+q) /(g-q)$ which becomes zero for $s=0$
} 
because asset prices need to be "multiplied" with some non-zero element. Secondly, the role of initial wealth may become important in the medium run ${ }^{6}$ with exogenous shocks, for example in cases of capital destruction or a collapse in real national income.

I use multiplicative equations to decompose wealth over longer periods, while additive equations are used to illustrate the nature of shocks. I also use the multiplicative model to interpolate ratio from point estimates; a common practice in this literature.

\subsection{Definitions and concepts}

From theory and wealth equations, I turn now to real world equivalents in the data.

\subsubsection{National wealth}

According to the UN SNA "national wealth is the sum, for the economy as a whole, of non-financial assets and net claims on the rest of the world." Defined institutionally, it is the sum of public and private ${ }^{7}$ wealth: the sum of financial assets (net of liabilities) and non-financial wealth for each sector. Aggregating across domestic institutions, financial claims net out to zero because financial assets of one sector equal financial liabilities of the others.

\footnotetext{
${ }^{6}$ Because $\beta_{\text {initial }}=\frac{W_{t}}{Y_{t+n}}=\beta_{t} /(1+g)^{n}$, the weight of this factor declines over the long run. See Section $\mathrm{C}$ of the online appendix for discussion of the details, merits and mechanisms of both equations

${ }^{7}$ Social accounting institutions can be further broken by claims into households, non-profit institutions serving households (NPISH), corporations, government and the rest of the world.
} 
In concrete terms, national wealth is the aggregation of three kinds of assets: unproduced (eg land), produced (eg machinery and dwellings) and net foreign wealth. In conjunction with the net-of-liabilities foreign asset position (NFA), national wealth can be written as:

$$
W_{t}=\underbrace{V_{t}}_{\text {Land }}+\overbrace{K_{t}^{\text {Produced assets }}}^{\text {P }}+N F A_{t} \equiv W_{p}+W_{g}
$$

Other non-financial assets such as precious metals (gold \& silver) are also part of national wealth, but I exclude them from benchmark calculations ${ }^{8}$ due to lack of consistent data. These assets play a much smaller role in the production side of the economy but do impact aggregate demand depending on saving preferences ${ }^{9}$ of households.

\subsubsection{Market value vs book value national wealth}

SNA definitions of national wealth correspond to perpetual inventory type methods (PIM). However, many newer estimates of wealth-income ratios follow Piketty and Zucman (2014) and estimate wealth using market values where corporate net worth is measured using the equity holdings of households. Book value national wealth equals market value national wealth plus the residual net worth of the corporate sector with both definitions converging when Tobin's q equals one.

\footnotetext{
${ }^{8}$ Using assumptions on data from scattered sources, alternative wealth series have also been computed; readers are referred to the supplementary database and online appendix for details. Inclusion of gold and silver increases the size of aggregate national wealth but on the whole their movements are not large enough to change any long run trends.

${ }^{9}$ Indian households hold gold and silver, although its weight in the personal wealth portfolio is more significant outside the top end of the wealth distribution. See Badarinza et al. (2017)
} 
Estimating market value wealth for India is both challenging, especially ${ }^{10}$ historically, and not necessarily better than the book value definition. Even in recent decades, listed corporate equities do not experience much trading (Allen et al., 2006). Inventories, which appear in book value, move faster and give a more updated sense of prices. Hence I only use book values in my series. In the appendix I discuss the pros and cons of either method for Indian series.

\subsubsection{Income and saving flows}

The definition of national income $(Y)$ is standard, i.e net-of-depreciation domestic product plus net factor income (NFIA) from abroad. The flow of savings $(S)$ are defined as net-of-depreciation capital formation plus net foreign investment and capital transfers from abroad. Coverage of saving flows, especially after 1950 is very complete and allows a full institutional decomposition of savings. Each institution's saving is the sum of capital expenditure and net lending. I use capital finance accounts to compute public sector (administrative government, public enterprises) savings. Private savings are derived as the residual of national less public sector saving flows.

\footnotetext{
${ }^{10}$ In the 1950s, according to industrial reports, Mukherjee and Sastry (1959) found market value national wealth to be quite well approximated by book value measurement. It is likely that Tobin's $\mathrm{q}$ was lower in the 1950-80 period because of financial repression and asset caps. In more recent years, evidence from samples of corporations suggests q is close to 1; roughly 1.1-1.2 in the 1990s (Khanna and Palepu, 2005) and around 0.94 for large Indian corporations in the 2000s (Allen et al., 2006).
} 


\subsection{Data sources}

Although my paper and dataset are the first to compute long run wealth-income ratios for India and link them to growth and saving flows, I follow in the tradition of several point estimates of national wealth in India. Atkinson (1902) made the first balance sheets for 1875 and 1895 for the colonial administration's tax revenue calculations. Using estimates from Atkinson (1902), survey estimates of land values, corporate reports and capital stock from Roy (1967), Goldsmith (1983) constructed detailed balance sheets on a decennial basis for the first half of the twentieth century. After independence, Mukherjee and Sastry (1959) and Mukherjee (1964) were commissioned by the official authorities to compute India's tangible wealth for 1950 and 1960; a follow up estimate was calculated by the central bank in statistical bulletins published in 1970 - these tables were the last complete estimate of wealth in India.

Due to the lack of official balance sheets, my data is constructed from drawing upon individual components in accordance with SNA definitions of book value national wealth. I combine official capital stock figures from the Central Statistical Organization (CSO) and land values from nationally representative ${ }^{11}$ surveys. All available post 1950 estimates of land values exclude the government and corporate sector's holdings. I adjust for these by adding 2 percent to the value of land owned by households. This figure was taken as an assumption based on estimates from 2012-14 asset disclosures of corporations and public entities. Needless to say, at this point all land changes are determined effectively by household's holdings. It

\footnotetext{
${ }^{11}$ The National Sample Survey Organization (NSSO) puts out a decennial All India Debt and Investment Survey (AIDIS) which estimates asset holdings of households
} 
is expected that in the future, these disclosures will allow the estimates of the full land component of national wealth. For pre-1960 estimates of national wealth, I draw upon the homogenous balance sheets attempted from multiple sources in Goldsmith (1983). Following SNA guidelines, consumer durables are excluded from net-of-depreciation fixed assets. Foreign balances are taken from the extended and updated dataset associated with Lane and Milesi-Ferretti (2007) and the Reserve Bank of India's official data.

For flows in the post 1950 period, I use official national accounts for all netof-depreciation flows i.e national income, capital formation, capital transfers, foreign investment at current prices. These series were obtained from the CSO's back-series archive of national accounts for 1951-2012, based on a combination SNA 93 and 08. I estimate the capital share of output exclusively for the organized sector - note that more than half of domestic output in India is produced by household enterprises (the unorganized sector) (Ghani et al., 2013) where income is split ${ }^{12}$ between labor and mixed income. More precisely, the capital share should correspond to production by organized businesses and corporations. To disaggregate saving rates, I computed financial flows for households using capital finance archives (also at CSO) for households and governments; corporate savings (and private savings) were estimated as a residual. For historical flows of total and sectoral output, income and saving I collected data from Sivasubramonian (2000) and Roy (1967). Nominal variables are adjusted when appropriate using the na-

\footnotetext{
${ }^{12}$ The high share of mixed incomes in developing countries is a well known issue. For distribution of domestic output, the issue is that non labor income most corresponds to self-employment income where small amounts of capital may be used, but the capital intensity of output is very small. See van Treeck (2020)
} 
tional income deflator at 2012 prices. Demographic data are taken from the World Bank Open Database and stock market series (market capitalization, price indices) were downloaded from the Federal Reserve of St Louis (FRED) database. Wealthincome ratios for other countries and cross-countries time series on top incomes shares were downloaded from the World Inequality Database. Final computations in the supplementary dataset are linked to all raw sources for replication.

\subsubsection{Note on series for 2018}

Most of my data and analysis stop in 2012. However, using the recently released official household wealth survey and official accounts for GDP, I extend the series by one data point to 2018. Note however that data after 2011-12 are steeped in some controversy. While the national accounts for 1950-2012 are constructed using a uniform methodology (CSO's official back series), India's official estimation methodology changed subsequently and economists have raised some concerns about an upward bias (relative to 1950-2012) in measured GDP (Nagaraj et al., 2016; Subramanian, 2019). Additionally, Anand et al. (2022) show that methodological changes in the 2018 official wealth survey miss a large fraction of wealth at the top of the distribution. Although separate sources show a sharp increase in the wealth of the rich, official estimates show a decline in top wealth shares for the first time since the 1980s. This raises some concerns about extending my methodology beyond 2012. I therefore restrict the use of the data point from 2018 to one series showing the long term evolution of wealth. 


\subsubsection{Limitations}

My dataset is limited in accuracy and should be seen as an imperfect attempt at estimating wealth in a developing economy whose official data collection practices are incomplete in scope; especially compared to OECD practices on quality control. However, several issues that I face are also common to other similar attempts to estimate wealth-income ratios in other countries. These include the challenge of hidden wealth in tax havens and sparse historical data. Reassuringly, my findings are in line with other related trends, such as top income shares and rents in the long run.

A major shortcoming with Indian data is that total wealth cannot be separately divided into public and private wealth due to lack of financial balances. There are two particular challenges. First, the Indian government made little attempt to account for its net assets in a systematic way. While public debt estimates are available (and provided in the supplementary dataset), these are not sufficient by themselves to compute net-of-liabilities financial ${ }^{13}$ assets. Secondly, the issue of illicit, hidden and under-reported household assets (such as cash and equities) are a huge challenge ${ }^{14}$ in Indian survey data; indeed, this problem motivated the 2016 demonetization experiment. At least one of public or private wealth should

\footnotetext{
${ }^{13}$ Since government accounts are disclosed for audit purposes, they simply cumulate past flows rather than following an accrual system. This works for financial loans but does not give a proper picture of capital assets. I use the IMF's accrual based estimate of public debt for core government (Abbas et al., 2011) as the benchmark debt series

${ }^{14}$ For instance, NSSO surveys show a decline in the population's stock market exposure between 2012 and 2018. However, the number of stock market trading accounts have (according to the RBI) increased from 20 to 35 million over this period.
} 
have complete financial information to distribute national wealth between both institutions. For these reasons, I only use national wealth as benchmarks for total wealth throughout this paper.

\section{The evolution of Indian wealth: 1860-2018}

\subsection{Historical background}

Given that a long period in Indian economic history is covered in the subsequent analysis, a recap ${ }^{15}$ of key historical facts and developments (albeit sweeping) is first in order. The British crown directly inherited India in 1858, ending the remnants of the Mughal Empire and dissolving administrative rights of the East India Company on the subcontinent. Thus, 1858-1947 is recognized as India's period under explicit colonial rule. According to Maddison (2001), India's share of global GDP fell ${ }^{16}$ from 6 percent to around 3.8 percent between 1870 and 1952. Over the course of British rule, growth of national income averaged ${ }^{17}$ 1.5-1.8 percent (1860-1947). Per-capita incomes, however, stagnated starting with the

\footnotetext{
${ }^{15}$ For more detail, see Roy (2002) and Tomlinson (2013) for a history of the colonial period and Lamba and Subramanian (2020) for the economy during the post colonial period.

${ }^{16}$ The most intensely debated aspect of colonial rule is its contribution to underdevelopment in India by the mid twentieth century. Recent estimates by Allen (2020) cite colonial rule as the main explanation for persistence of extreme poverty in India during the late twentieth century. Per-capita incomes in Britain and India diverged over the de-facto (Company) and official colonial period to the point that average Indian incomes became a fraction of British median incomes by the time of independence. According to Broadberry et al. (2015), the bulk of the divergence occurred just prior to the Crown taking over administrative control.

${ }^{17}$ From Heston (1983) and Sivasubramonian (2000)
} 
second decade of the twentieth century. Thus, while there was some investment (particularly in irrigation) and per-capita income growth towards the end of the nineteenth century (Tomlinson, 2013), most economic growth in the remainder of the colonial period is attributable to a demographic boom; population growth took off following a systematic mortality decline around 1921 (Guha, 1991). Agriculture was central to the economy; over 70 percent of the workforce was tied to it, but agricultural GDP only increased by 15 percent over 1900-46 (Roy, 2006). In contrast, and conditional on the small share of employment and output in industry, indigenous capitalists were thriving; non-agricultural output (real) nearly doubled and industry cultivated foreign markets and imported skilled labor. Factory output was growing at a gross rate of 4-5 percent (Roy, 2016). Thus, the impact of the interwar era was not homogenous. While top income shares in India peak in this era (Alvaredo et al., 2017; Chancel and Piketty, 2019), static wages, collapse of the agricultural economy and more mouths to feed exacerbated rural poverty.

At independence, the new political leadership of India decided to confront India's unequal, poor and mostly agricultural economy with state-directed, or planned, economic development. Early roots of these plans ${ }^{18}$ are traced to a collaboration between political and industrial elites on the eve of independence.

\footnotetext{
${ }^{18}$ India's leading industrialists gave an economic outline in the 1945 "Bombay Plan." While Nehru (the first Indian Prime Minister) had mixed feelings towards the importance of private industry, it is generally agreed that India's first two five year plans were de-facto adoptions of the Bombay Plan. Economic historians have identified this development in two ways. (1) It was the best way for industrialists to protect themselves from global competition and (2) Building domestic industrial strength was a reaction to the foreign laissez faire type operations which nationalists identified as diffusing underdevelopment in British India. See Roy (2016)
} 
Through 1950-75, successive governments continued on a path of nationalizations of key sectors: air and rail transport, banking, coal and public utilities. Meanwhile, the broader private corporate sector shrank through expansive corporate taxes and industrial licensing. Redistributive policies took on an explicit anti-rich narrative (Kumar, 2020). In the immediate years following independence, land reforms were enacted and landlordism was abolished. Also, through the 1950s, several progressive taxes on wealth, estates and incomes were implemented. By the 1970s, top marginal income tax rates became high to the point of confiscatory (Acharya, 2005).

Despite explicit measures to take control of the development process, the state was unable to deliver substantial rates of economic growth. India's low growth between 1950-80 is sometimes referred to as the "Hindu growth" era, distinguishing it from other Asian economies on account of cultural norms. Catch-up type rapid growth, expected during the Hindu growth period, actually began in the 1980s. The key reason, according to Rodrik and Subramanian (2005), was a change in political attitudes towards private business. Economic reforms followed in the early 1990s (Ahluwalia, 2002), shifting the environment substantially in favor of private capital and foreign investment. In particular, asset caps on large firms and industrial licensing were dismantled, tax rates were reduced and private capital was invited into key sectors via a series of reverse nationalizations in the late 1990s and early 2000s. Between 1980 and 2018, per-capita economic growth averaged over 4.5 percent, putting India in a small set of countries to exhibit impressive growth over a sustained period during the post-war era (Lamba and Subramanian, 2020). According to IMF estimates, India's share of world GDP returned back to 
6 percent by 2012 .

\subsection{Documenting the facts}

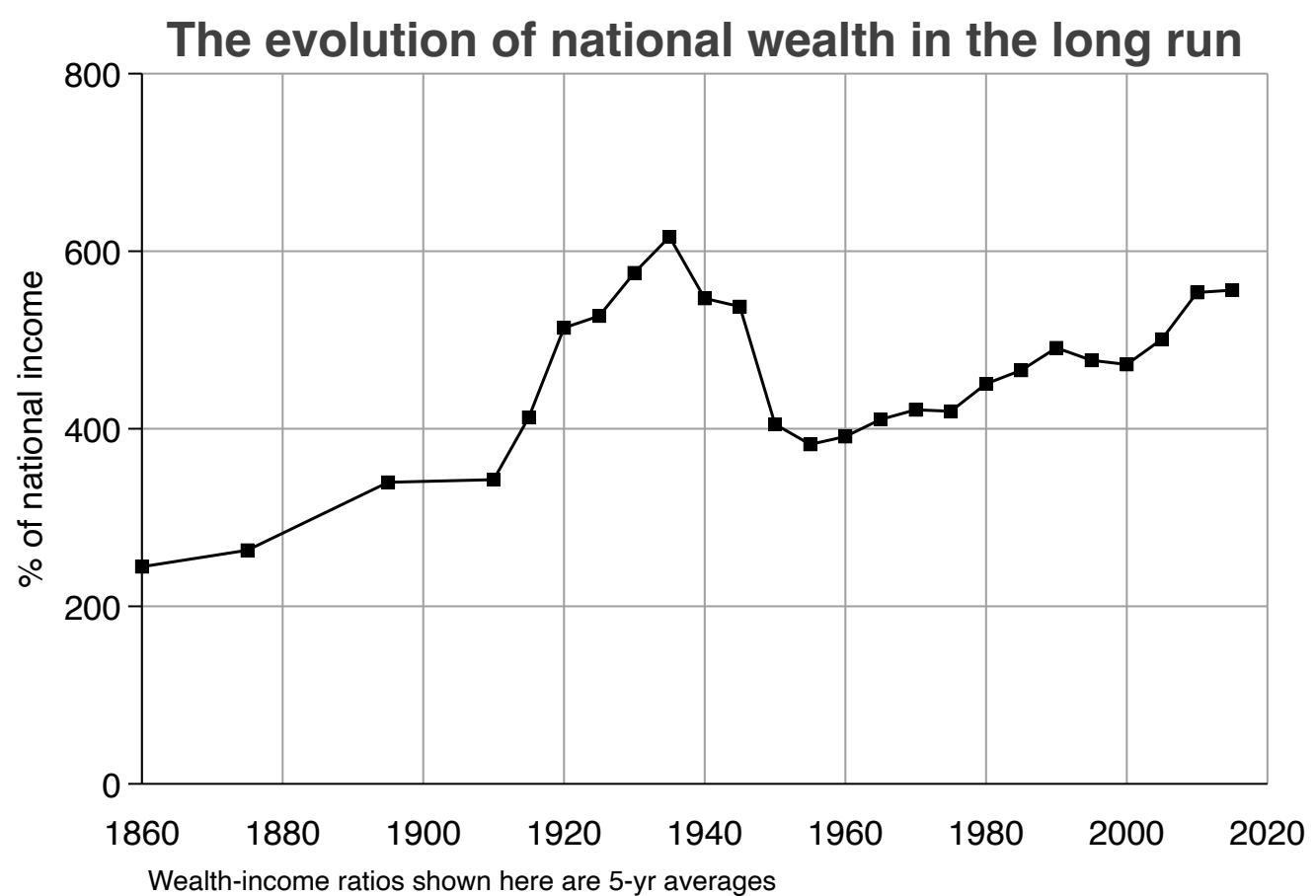

Figure 1: Wealth-income ratios, India: 1860-2018. Author's computations in supplementary dataset

To start, let me present the central result from my dataset: the series in Figure 1 shows the evolution of wealth-income ratios in the long run (1860-2018). I stress again - the further back in time we go with these data, the more we move away from precision, and veer towards speculation. There is, however, a clear pattern observed over fifteen decades; Indian wealth increases as a ratio to national 


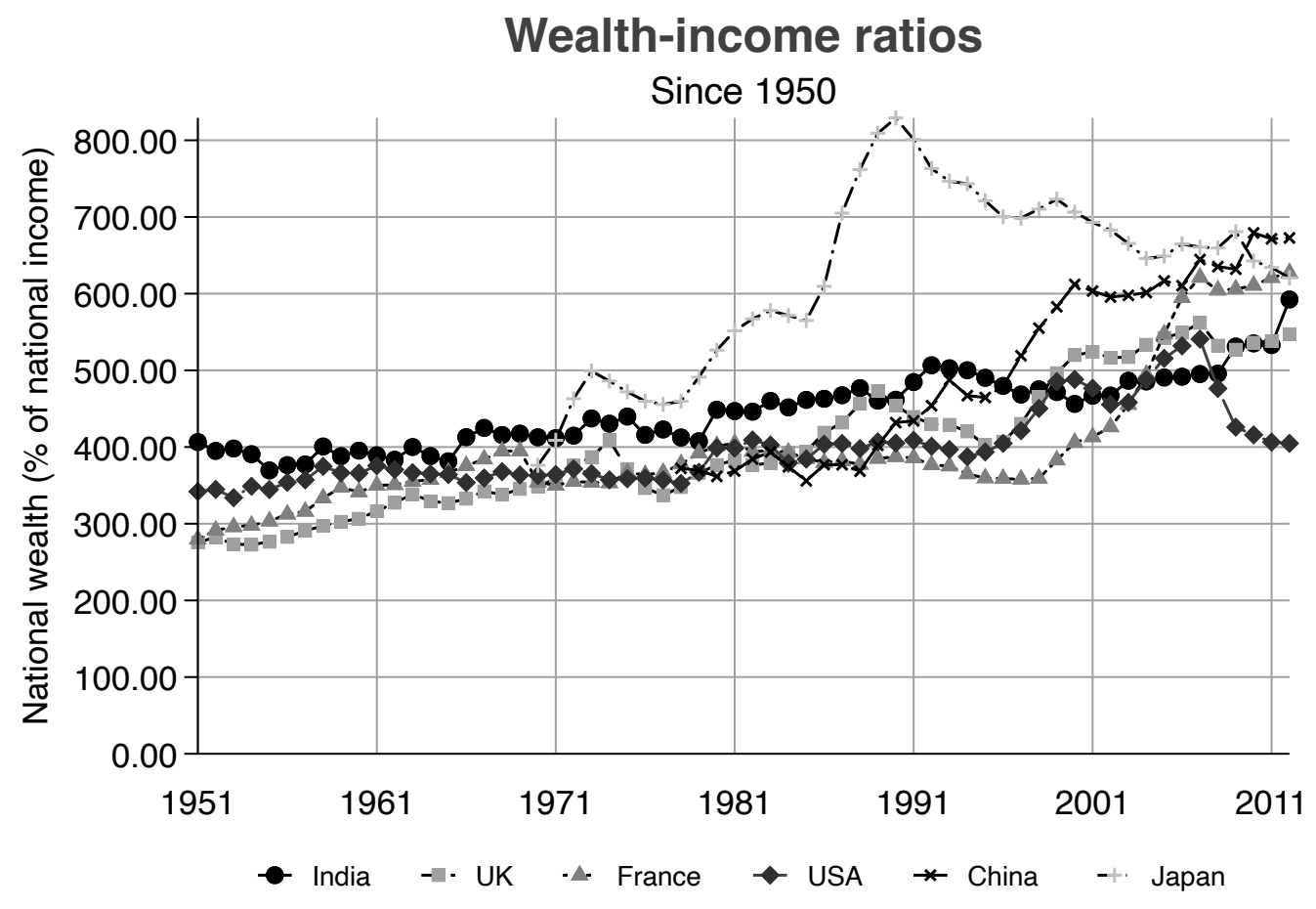

Figure 2: Wealth-income ratios in major economies: 1950-2012. Author's computations in supplementary dataset and World Inequality Database

income over 1860-2018. In the second half of the nineteenth century (colonial period), wealth-income ratios were around 200-300 percent and ended up between 550-600 percent in the early twenty first century. Although $\beta$ takes on relatively larger values in the twenty first century, there is a noticeable spike in the interwar period. A big part part of the subsequent material in this paper tries to explain this as a temporary fluctuation whose effects are not structural from a long run perspective. 
Now, focusing on the second half of the twentieth century, where data are much more reliable and collected from official sources, I compare wealth-income ratios in India to other countries: UK, France, USA, China (1978 onwards) and Japan (1968 onwards). These series are shown in Figure 2. Indian ratios follow a similar pattern to UK, France and USA in that there is a gradual increase over 1950-2012, compared to a sharper rise in China and Japan's extraordinary bubble in the 1980s and 1990s. The erraticism of the first half of the twentieth century gives way to a smoother upward trend. However, the rise of Indian wealth is most impressive, and in fact only comparable to China, because it occurs alongside rapid economic growth after the 1980s. Meanwhile, as Piketty and Zucman (2014) show, rising wealth-income ratios in the rest of the countries in this sample occurred alongside a progressive slowdown in economic growth.

A second point of difference in these comparative trends is a "comeback" effect in rich countries, versus long run wealth accumulation in capital-poor countries like India and China. European ratios, for example, used to be high in the nineteenth century. Their rise in the twentieth century is more a return to the past compared to a process of capital accumulation and economic development which best describes India in the long run. To shed more light on this, I convert $\beta=W / Y$ into an index, normalized to 1895 values $(1895=100)$ and compare with France, UK and USA, in Figure 3. Indian ratios, as mentioned previously, rise over time, relative to the low levels prevalent at the end of the nineteenth century. European (and American) wealth, on the other hand, collapses in the first two decades of the twentieth century and spends the next ten decades recovering to its levels of the nineteenth century; the comeback of European wealth-income ratios in the 


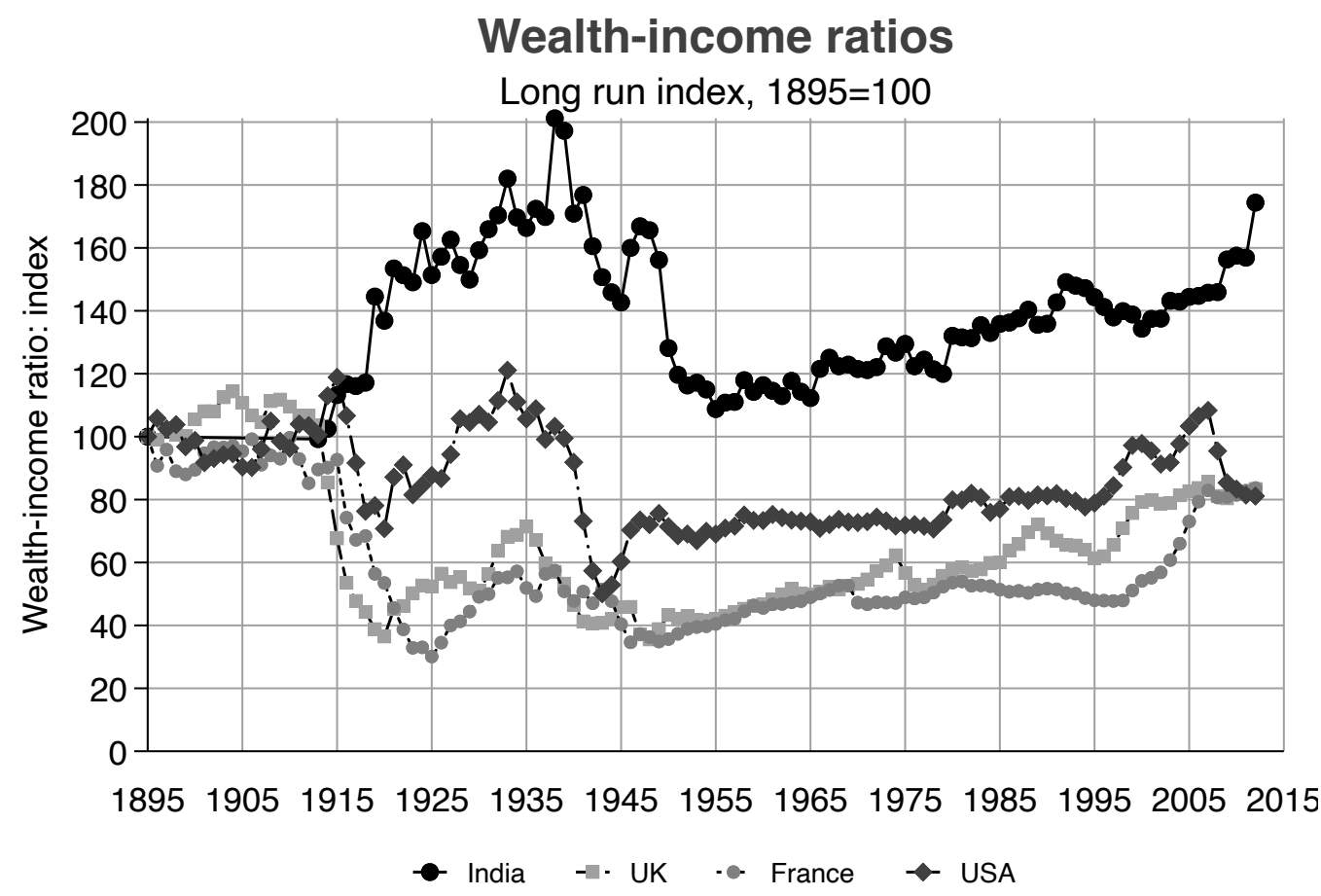

Figure 3: Wealth-income ratios in India, European countries and USA in index form $(1895=100)$. Author's computations in supplementary dataset and World Inequality Database

twenty first century plays a prominent role in Piketty (2014). The first half of the twentieth century illustrates this effect; gap emerges between India and rich countries due to divergent trends in the first two decades, and thereafter all countries undergo a similar spike between World War I and II. The fact that all countries in this sample share the spike also suggests that while data may be imprecise, the turbulence between the Great Depression and World War II is not a country-specific measurement error. 


\subsubsection{The structure and composition of Indian wealth}

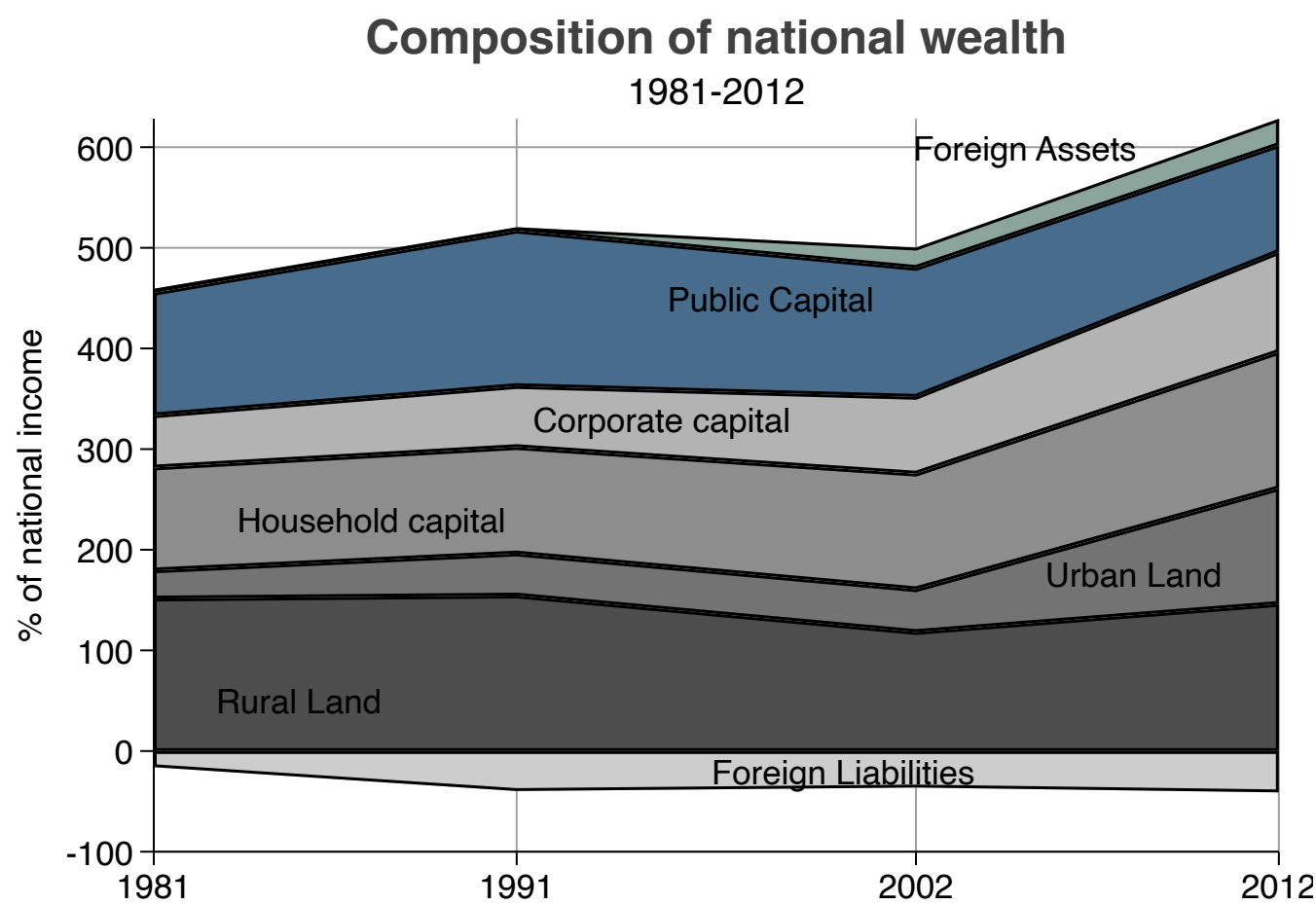

Figure 4: Composition of national wealth, 1981-2012. Author's computations in supplementary dataset

Turning now to the composition of national wealth, I first focus on recent decades using institutionally detailed official data on capital and urban/rural land. These data are shown in Figure 4 for the period 1981-2012. Foreign wealth is shown to be negligible, although the lead up to the 1991 balance of payments crisis is evident because claims on the rest of the world only show up afterwards, whilst liabilities built up over time. Capital dominates the structure of wealth, although land is not far behind. Indeed, India has struggled to shed its traditional 
economy despite public capital shrinking to make space for capital accumulation in the corporate sector; rural land declined over this period but even in 2012, it constituted between 1-2 years of national income. Most remarkably, households' role in production remains fairly strong given that household capital has remained stable throughout this period of rapid economic growth.

A long standing trend in Indian wealth is the relatively high importance ${ }^{19}$ of land. Comparatively, in industrialized countries, the substantial weight of agricultural land fell quite swiftly in the twentieth century, getting replaced by urban real estate. Since over 65 percent of the Indian population resides in rural India as recently as 2012, the same is obviously unlikely. But there was some change starting in the 2000s as the share of urban land (basically real estate) finally off. This trend reflects growing importance of cities as the locus of production ${ }^{20}$ in India's services-led economy (Eichengreen and Gupta, 2011), and an indication that despite the overhang from traditional economic activity, the transition to the modern sector is in fact ongoing.

Due to the delayed growth takeoff, India remained quite underdeveloped for most of the twentieth century, and this is reflected in the long run composition of wealth (Figure 5). In recent decades, capital and wealth move together; in

\footnotetext{
${ }^{19}$ Most personal wealth in India is held in real estate, with land being the major component of rural real estate. See Badarinza et al. (2017).

${ }^{20}$ Concentration of employment into a few major cities drove higher urban incomes and a real estate/construction boom (Lamba and Subramanian, 2020). Urban prices were always likely to spike under pressure from in-migration because India is shown to lack large cities, relative to the size predicted by Zipf's law (Chauvin et al., 2017).
} 


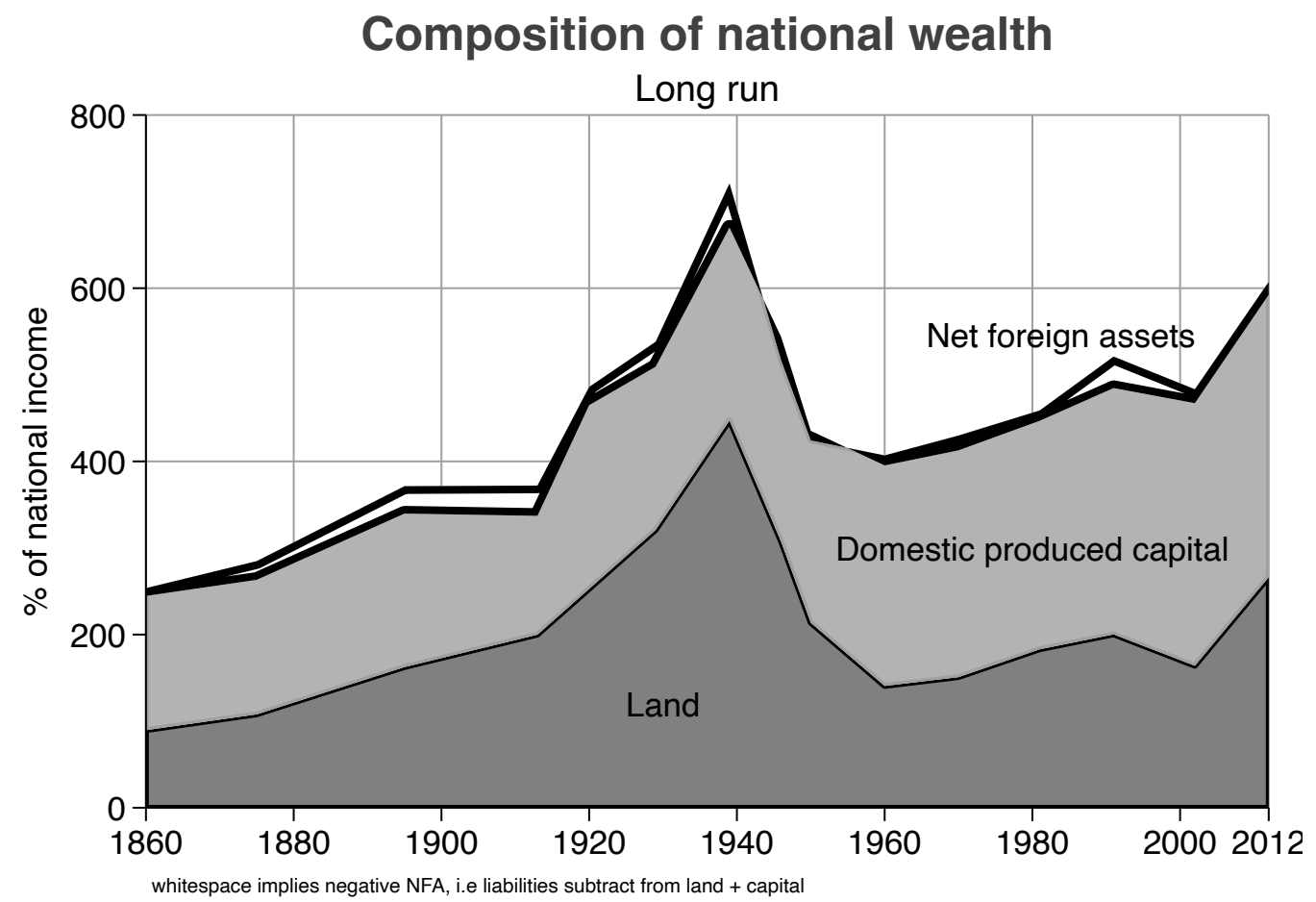

Figure 5: Composition of national wealth in the long run. Author's computations in supplementary dataset

the past, their movements were not necessarily related. Agricultural shares of output declined consistently through the twentieth century (Figure 6), but wealthincome ratios followed the land-to-national income ratio. That is, in the absence of broad reaching and well developed capital markets, dynamism in wealth came from fluctuations in land value. Initial increases over the late nineteenth-early twentieth century were driven ${ }^{21}$ by land markets which themselves were fed by

\footnotetext{
${ }^{21}$ Starting in the late nineteenth century, colonial policy actively aimed to increase agricultural output in less irrigated areas via investment in canals. As Roy (2002) points out, these policies
} 


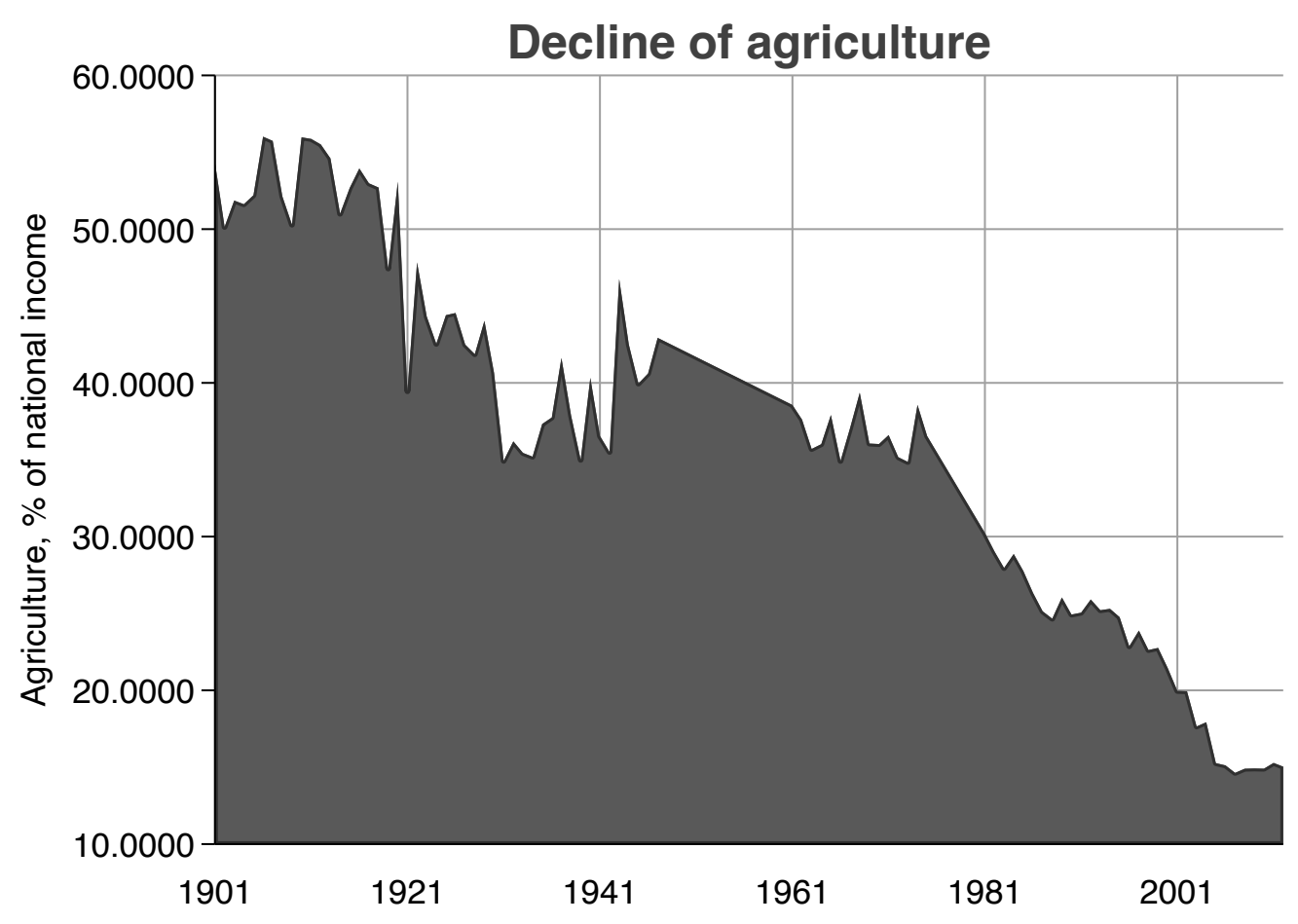

Figure 6: Share of agriculture in national income in the long run. Author's computations in supplementary dataset

commercialization of agriculture and expansion of area under cultivation (Blyn, 1966; Tomlinson, 2013).

The interwar hill in Figure 5 marks the end of volume based expansion, with a slowdown in economic growth beginning to take root (Roy, 2002), and the start of a two decade land price cycle. As Figure 7 shows, the "hill" is mostly a denominainteracted with commercialization of agriculture to energize the land market, resulting in a rise in land rent and prices. 


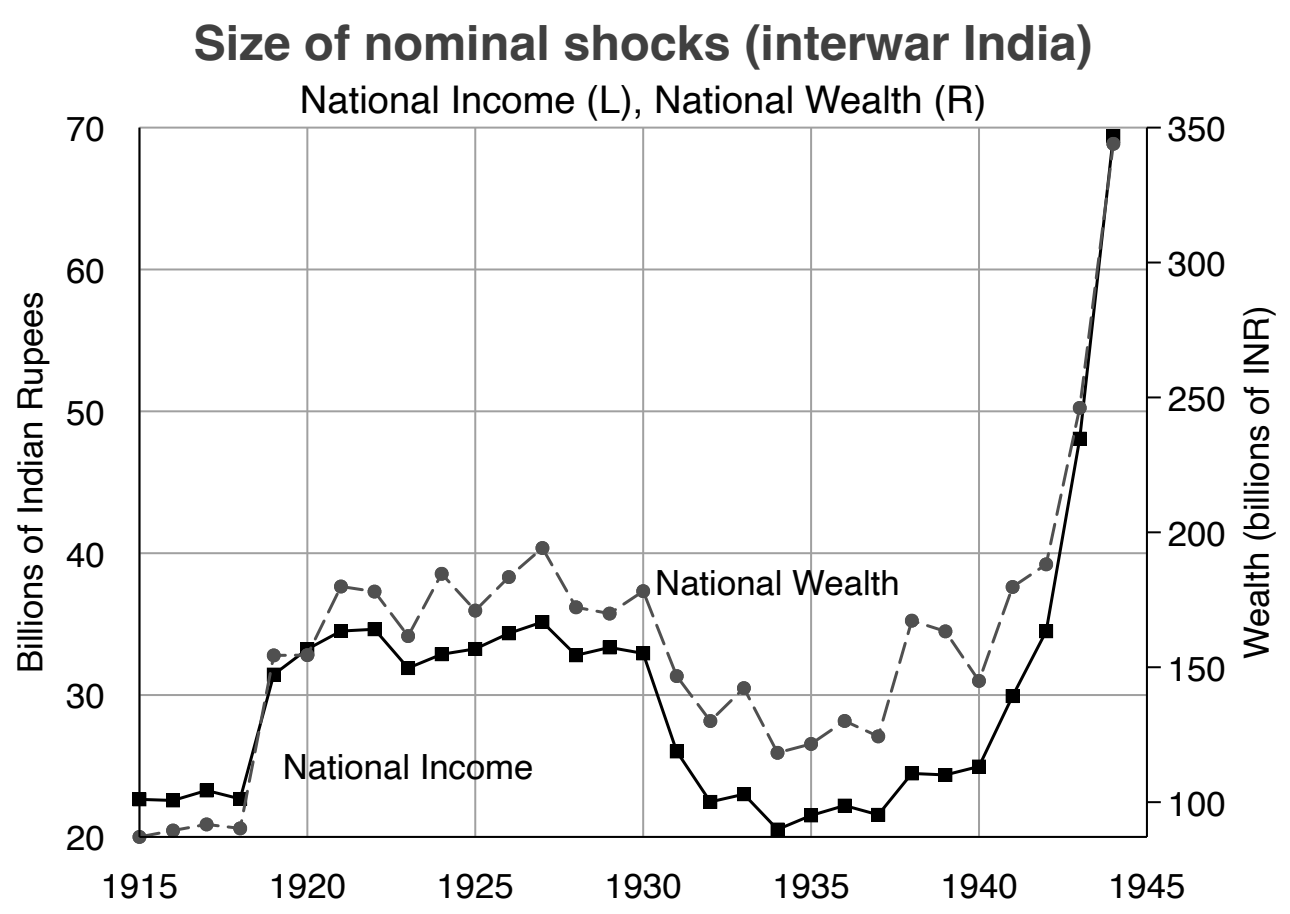

Figure 7: Nominal values of national wealth and national income during the interwar period. Author's computations in supplementary dataset

tor effect due to a greater collapse of nominal national income. These differential deflations $^{22}$ raised relative asset prices (land), generating capital gains on landholdings which were eventually canceled out by capital losses during the World War II food price inflation. During the relative surge in asset prices, wealth and income shifted in favor of the rich while the vast majority became impoverished.

\footnotetext{
${ }^{22}$ As writers on India's experience with the Great Depression observe, land prices only stagnated
} at a time when output prices were collapsing and rent demands on peasants showed no restraint (Rothermund, 1980). 


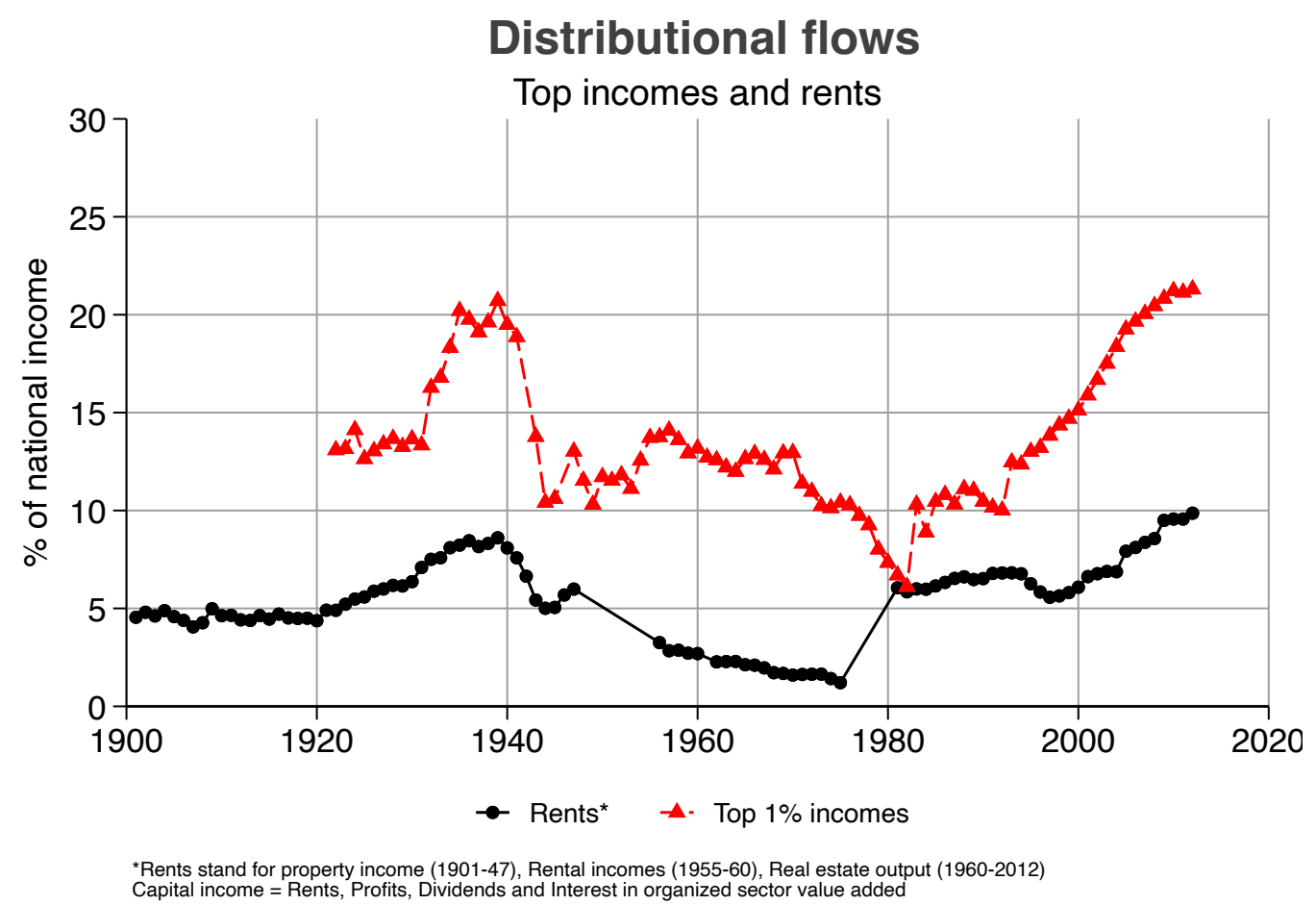

Figure 8: Income distribution in the long run. Author's computations in supplementary dataset and World Inequality Database

These trends also bear out separately in the distribution of income and rents (Figure 8), both of which swell and shrink with similar intensity during that period. Without any war related destruction, capital remained stable and filled into the share of total wealth during the following decades thus creating a joint increase in the capital-to-national income ratio, as well as aggregate wealth-income ratios. 


\subsection{Explaining the main trends}

In the historical analysis of wealth, capital destruction plays a fundamental role because much of what is known in the long run is derived from European countries (Piketty, 2014). These countries were mostly industrialized and had already accumulated substantial capital by the early twentieth century. Thus, the main ingredient of the U-shaped trend in France and the UK is driven by a geopolitical shock $^{23}$ which decimates part of $W$ in $\beta=W / Y$, only for steady state conditions $(\beta=s / g$ ) restoring wealth back to predicted values. The lesson from the Indian experience is that economic factors can also create violent looking trends - as we have seen. Ultimately, price effects and capital accumulation are the main explanations of the evolution of wealth-income ratios in India. This is especially important because of the variation in rates of economic growth over the course of the twentieth century.

\begin{tabular}{lllllll}
\hline Time period & National Income & National Wealth & Saving Rate & $\beta=\mathrm{W} / \mathrm{Y}$ & Population growth & Per-capita Income \\
\hline $1913-1950$ & $0.97 \%$ & $1.67 \%$ & $2 \%$ & $394.84 \%$ & $0.97 \%$ & $0.00 \%$ \\
$1950-1980$ & $3.82 \%$ & $3.91 \%$ & $10 \%$ & $444.13 \%$ & $2.14 \%$ & $1.68 \%$ \\
$1981-2012$ & $6.05 \%$ & $6.91 \%$ & $23 \%$ & $556.61 \%$ & $1.84 \%$ & $4.21 \%$ \\
\hline
\end{tabular}

Table 1: Growth and saving rates, India: 1913-2012. Author's computations in supplementary dataset.

In Table 1 , I present period-wise averages of $\beta$ along with rates of saving and national income growth. These periods represent important regimes in Indian his-

\footnotetext{
${ }^{23}$ Another competing hypothesis is put forward recently by Waldenström (2021) who argues for the role of institutions in rich countries, and the democratization of financial wealth for the majority during the twentieth century. In the case of the Spanish civil war, destructive losses were compensated with land price appreciation (Artola et al., 2021)
} 
tory, but also correspond to point estimates of wealth-income ratios in my dataset. The bottom line is that averages for economic growth and $\beta$ increased over time. In fact, the fluctuations prior to 1950 canceled themselves out. $\beta$ averaged 390 percent prior to independence, 444 percent for the first three post-independence decades and increased to over 550 percent by the end of the twenty first century. These averages point more strongly to economic development and wealth accumulation occurring together, as opposed to the AJR institutional hypothesis which predicts lower wealth-income ratios after the dismantling of extractive colonial institutions. Further, the metamorphosis of national income also leans in favor of endogenous saving and growth rates which were themselves the result of an ongoing dual-sector growth process. Figure 9 shows that the saving rate, along with shares of the organized sector, corporate investment and capital income all increased together, coinciding with India's growth takeoff in the 1980s.

The positive relationship between wealth accumulation and economic growth goes back to the fundamental challenge of economic development (increasing the saving rate in a poor economy), raised originally by Lewis (1954). More specifically, Lewis proposed that under favorable investment conditions, the modern sector of a labor surplus economy could bootstrap towards higher growth by "fructifying" per-worker output with capital. Faster productivity growth (over wages) would increase the capital share of output, as well as per-capita income, both of which would lead to higher saving rates and more capital accumulation to economic progress further. Most importantly, such economies are too far from steady state; an inverse relationship between $\beta$ and $g$ (as in $\beta=s / g$ ) is simply not realistic. 


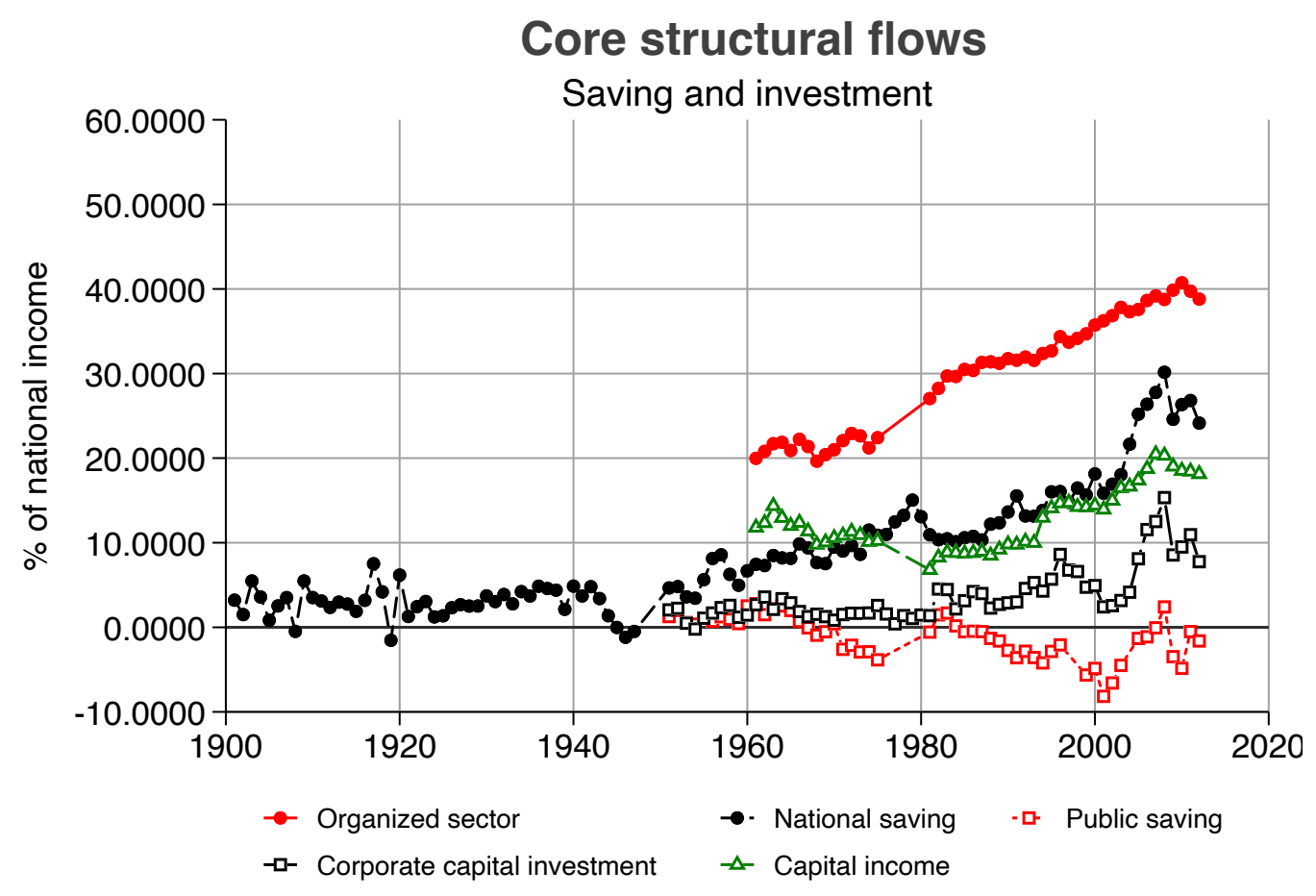

Figure 9: Structural changes to national income in the long run. Author's computations in supplementary dataset

While a dual-sector model is a good explanation for $\beta \propto g$ during India's catchup phase, this does not preclude large episodic variation in $\beta$ when $g$ approaches 0-1 percent; at low growth rates, price effects become important. That is, in periods when growth is absent, whether the economy is rich or poor, a small change in asset prices can compound and produce the large swings observed prior to Indian independence. Note that India's Hindu growth period (1950-80) was hardly impressive in comparison to the rest of Asia's emerging economies. But a growth rate of 1.5-2 percent per-capita is still superior to 0 percent, as was the case prior 
to 1950 . The mathematical relationship can be understood using the multiplicative wealth equation for $\beta$ :

$$
\beta_{t+1}=\beta_{t}\left(1+g_{w s}\right) \frac{(1+q)}{(1+g)}
$$

The relative effect of economic growth is represented by $\frac{(1+q)}{(1+g)}$. The point is, even a small real rate of capital gains $(q>0)$ multiplies quickly at low rates of economic growth. To be sure, both capital gains and losses can take excursions, such as those observed in interwar India. Obviously, asset price inflation remains relevant even for modest rates of economic growth; for instance, the increase in urban land values in India after 2000 (shown previously). However, for $g$ increases beyond the absolute values of $q$, the multiplicative effect loses potency.

\begin{tabular}{|c|c|c|c|c|c|}
\hline Time Period & $\begin{array}{c}\text { Initial wealth } \\
W_{t} \\
\end{array}$ & $\begin{array}{c}\text { Final wealth } \\
\qquad W_{t+n} \\
\end{array}$ & $\begin{array}{c}\text { Wealth Growth } \\
\qquad g_{W} \\
\end{array}$ & $\begin{array}{c}\text { Saving induced growth } \\
\qquad g_{w s}=s / \beta \\
\end{array}$ & $\begin{array}{l}\text { Price effects } \\
q=\frac{1+g_{W}}{1+g_{w s}}-1 \\
\end{array}$ \\
\hline \multirow[t]{2}{*}{$1913-1950$} & $9,635.71$ & $17,761.82$ & $1.67 \%$ & $0.59 \%$ & $1.07 \%$ \\
\hline & & & & $35.50 \%$ & $64.50 \%$ \\
\hline \multirow[t]{2}{*}{$1950-1981$} & $17,761.82$ & $58,277.65$ & $3.91 \%$ & $2.41 \%$ & $1.46 \%$ \\
\hline & & & & $62.22 \%$ & $37.78 \%$ \\
\hline \multirow[t]{2}{*}{$1981-2012$} & $58,277.65$ & $462,543.99$ & $6.91 \%$ & $5.08 \%$ & $1.75 \%$ \\
\hline & & & & $74.42 \%$ & $25.58 \%$ \\
\hline
\end{tabular}

Table 2: Decomposition using multiplicative wealth equations. Author's computations in supplementary dataset

With these ideas fixed, I now answer the question: how did the importance of price and volume effects change over time? Using Equation 2, I decompose the growth rate of wealth into its saving induced component $\left(g_{w s}=s / \beta\right)$ and the real rate of capital gains (Table 2). Given low rates of saving, price effects explain 
nearly two-thirds of the increase in wealth over 1913-1950. Note the relative size of $q$ in historical terms; although $q$ increases over time, it becomes synthetically important owing to low growth of wealth itself during 1913-1950. As also shown in Figure 7 , the increase in relative asset prices is driven by a collapse ${ }^{24}$ of the nominal price of output. Obviously, the average value of $q$ includes both capital gains and equally sharp capital losses for the pre-1950s. Moving on to later periods, as argued earlier, the contribution of $q$ declines as economic growth picks up, during the mixed economy phase (or "Hindu growth" era). The latest, and fastest, period of economic growth relegates the effect of asset prices to just one-fourth; the implication is that much of the accelerated increase in $\beta$ during 1980-2012 is driven by capital accumulation ${ }^{25}$ over the path of development.

\section{Discussion: $\beta$ and economic growth}

The rise of Indian wealth-income ratios over time puts a new spotlight on the relationship between economic growth and wealth accumulation. The general consensus, as explained so far, relies on evidence from countries whose industrialization and per-capita income put them much closer to steady state. Accordingly, variation in $\beta$ is inversely related to economic growth through $\beta=s / g$. Piketty

\footnotetext{
${ }^{24}$ See Blyn (1966) for commodity price indices for 1867-1947. Blyn's series show a striking decline in agricultural and non-agricultural price indices, following the Great Depression. Taking $1900=100$, prices tripled by the early 1920s and then quickly plummeted after 1929.

${ }^{25}$ The results are similar using additive equations with an added role for initial wealth. Under low growth, initial wealth appears large because national income increases very little; remember that initial wealth is given by $\frac{W_{t}}{Y_{t}(1+g)}$. These decompositions are available in Table $3 \mathrm{~b}$ in the supplementary dataset
} 
and Zucman (2014) use this formula both inter-temporally, and across countries. Higher $\beta$ in Europe (relative to USA) is explained by lower growth rates; and, the productivity slowdown in rich countries explains the universal rise of wealthincome ratios in the twenty first century (Piketty and Zucman, 2014). But once we include India and China into this mix, obviously, the relationship "turns" positive. In this section, I take a deeper look at the dynamism of $\beta$ at different rates of economic growth.

\subsection{Economic growth and $\beta$ : the Indian perspective}

As suggested in Table 1, the correlation between economic growth and wealthincome ratios in India is positive in the long run. Still, this does not absolve the fact that some of the highest wealth-income ratios in the twentieth century occur in the period of zero economic growth (the 1930s). Put simply, a positive structural association between $\beta$ and $g$ does not rule out chaotic fluctuations at extremely low growth rates. Therefore, we observe two patterns in the data: rising wealth-income ratios and per-capita incomes in time, but also instances of high wealth-income ratios - due to more variability - as $g$ approaches zero.

To add clarity, I split my data series over 1913-2012 into pre and post-1981 buckets; given that long run data are most certainly fragile, this selection is neither exact, nor econometrically identified. Rather, I anchor it on India's historical background. As Rodrik and Subramanian (2005) stress, productivity growth emerged in the 1980s, with sustained capital accumulation driving India out of its economic lull. Prior to 1981, economic growth was constrained to a low mean, remaining nearly stagnant in the pre-independence years, and showing some life 


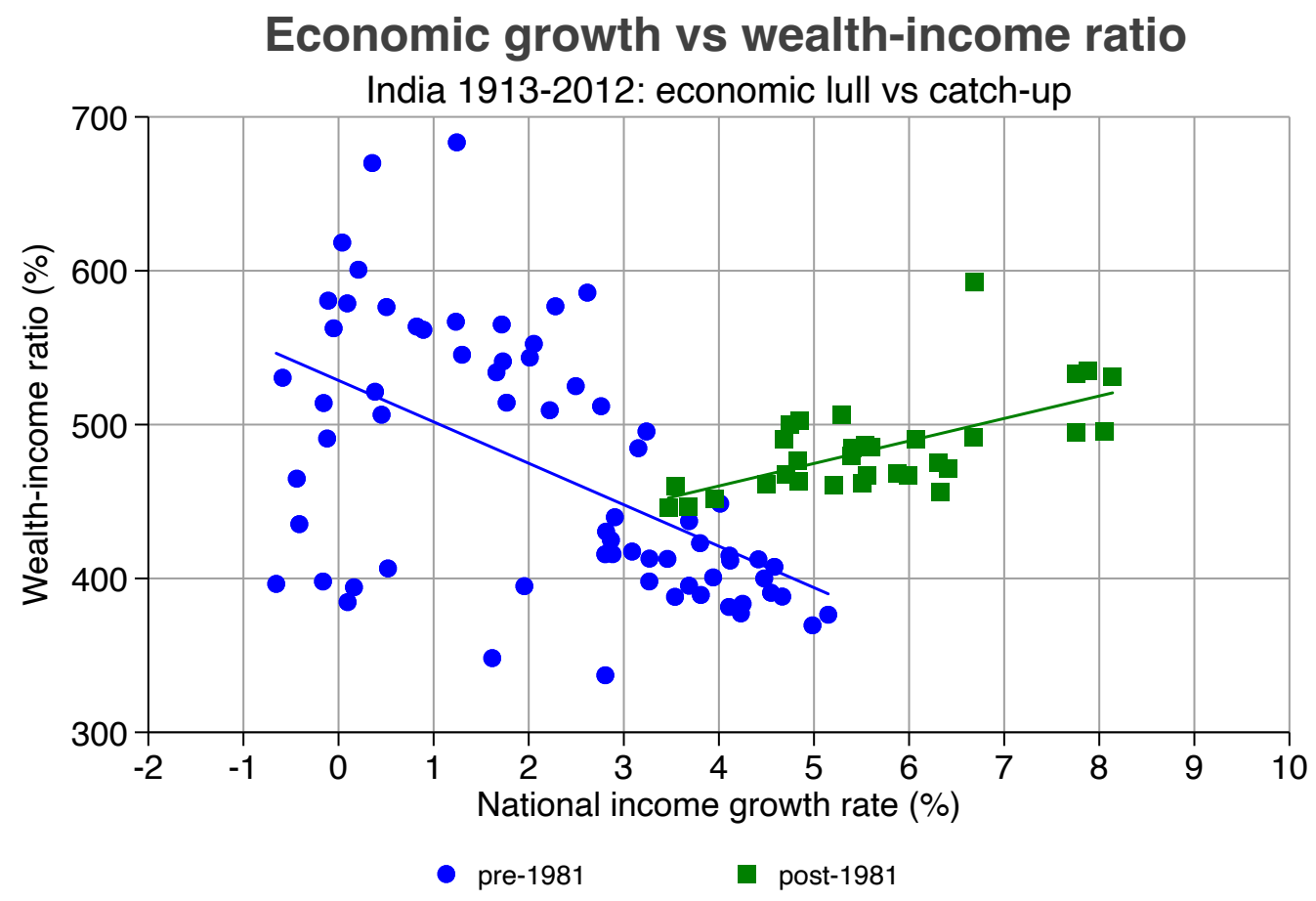

Figure 10: The relationship between $g$ and $\beta$ before and after 1981. Author's computations in supplementary dataset

with positive rates in the next three decades. Figure 10 shows a scatterplot of $\beta$ as a function of $g$ for both these buckets. Quite clearly, for the low growth period (1913-1980), the data collapses on a downward sloping line. For the post-1981 bucket, $\beta$ shows positive association with $g$. The inversion of this relationship, from $\beta \propto 1 / g$ to $\beta \propto g$ suggests a potential turning point, or a U-shaped relationship between wealth-income ratios and economic growth for sufficiently wide growth bands. The turning point is basically driven by the bootstrapping effect between capital accumulation and economic growth as sustained high growth rates 
push the economy towards catchup.

In effect, while one should not expect wealth-income ratios to behave similarly in emerging and advanced economies, these differences take root most emphatically during the catchup phase. In emerging economies, the characteristic of economic development in its most reduced form is a sustained increase in per-capita incomes. All heterogeneity aside, higher mean incomes beget more wealth as the fraction living above subsistence increase ${ }^{26}$ in time, and rising wealth-income ratios make sense; both individually, and for the aggregate. On the other hand, when the long run evolution of the economy is constrained around a low growth range, $\beta$ becomes subject to larger variation from small perturbations in asset prices; the level of economic development in this case is secondary to the mathematics of compounding. As the Japanese bubble of the 1980s, or the interwar era excursions in India, France and UK show, the imperialism of low growth rates does not discriminate on the basis of per-capita incomes. In fact, as Piketty and Zucman (2014) argue, the return of wealth-income ratios in rich countries is explained by the rebound of asset prices, due to pro-capita policies, occurring as the growth slowdown began to take hold.

\subsection{Economic growth and $\beta$ : a comparative perspective}

To test the comparative strength of the U-shaped relationship between $\beta$ and $g$, I analyze cross-country variation using the sample of countries shown in Figure 2

\footnotetext{
${ }^{26}$ Importantly, the capital share in India has increased, as the modern (organized) sector absorbs a larger share of output. In comparison, capital shares in rich countries, according to the latest estimates, appear trendless (Waldenström, 2021).
} 
for the post-1980s. A coincidence of timing is particularly useful: the slowdown in rich countries' growth rates occurred at the same time as the economies of India and China took off, thereby giving a wide range of economic growth rates. The main hypothesis I test is whether the presence of the latter two emerging economies wears out (to the point of turning) the otherwise inverse relationship between $\beta$ and $g$.

I obtained per-capita growth rates and per-capita incomes ${ }^{27}$ for India, China, Japan, USA, France and UK from the World Development Indicators and tested the basic model:

$$
\beta_{i t}=b_{0}+b_{1} g_{i t}+b_{2} g_{i t}^{2}+u_{i t}
$$

In equation $6, i$ stands for country $i$ at time $t$. Basically, equation 6 tests if the relationship $\beta \propto 1 / g$ switches beyond a growth threshold. That is, the expected sign for $b_{1}$ is negative but $b_{2}$ should be positive. No causal relationships are implied and this exercise is intended only as supplementary cross-country evidence for the argument I have made to explain the shape of Indian wealth-income ratios in the long run.

Results for this model are shown in Table 3 and the signs agree with my proposed hypothesis. Column (1) in the table shows a basic regression which tests equation 6 as-is, with coefficients on $g$ and $g^{2}$ significant at least at the 1 percent level. As expected, the sign of $b_{1}$ is negative (or, $\beta \propto 1 / g$ ) and the sign of $b_{2}$ is

\footnotetext{
${ }^{27}$ Per-capita incomes were calculated in constant (2015) US dollars. Wealth-income ratios were downloaded from the World Inequality Database
} 
(1)

Wealth-income ratio (\%) Wealth-income ratio (\%)

\begin{tabular}{lll}
\hline \hline Growth rate (\%) & $-11.79 * *$ & $-11.33^{* *}$ \\
& $(3.747)$ & $(3.900)$ \\
Square of growth rate (\%) & $1.561^{* * *}$ & $1.594 * * *$ \\
& $(0.307)$ & $(0.300)$ \\
Log p.c. income, constant dollars (2015) & & 3.858 \\
& & $(3.444)$ \\
Constant & $515.7 * * *$ & $477.7 * * *$ \\
& $(10.91)$ & $(31.56)$ \\
\hline Observations & 172 & 172 \\
Adjusted R-squared & 0.065 & 0.062 \\
& & \\
\hline Standard errors in parentheses & & $* * * \mathrm{p}<0.001 \%$ \\
"* $<<0.05$ & $* * \mathrm{p}<0.01$ &
\end{tabular}

Table 3: Regression results $\beta$ versus $g$, 1981-2012. Countries in sample include: India, China, Japan, USA, France and UK. Data from author's computations in supplementary dataset, World Inequality Database and World Development Indicators

positive, indicating that the inverse relationship between $\beta$ and $g$ tails off beyond a point. Next, I ran the same model but with the log of per-capita income added as a control variable. Column (2) retains the same signs as column (1), with both coefficients significant at least at the 1 percent level; however, per-capita income and wealth-income ratios have no significant relationship. From the estimates in Column (1), as a first approximation, I calculated the turning point ${ }^{28}$ - where

\footnotetext{
${ }^{28}$ Since $\beta_{i t}=b_{0}+b_{1} g_{i t}+b_{2} g_{i t}^{2}+u_{i t}$, the turning point is that value of $g$ that solves $\partial \beta / \partial g=$ $b_{1}+2 b_{2} g_{i t}=0$
} 
the relationship between $\beta$ and $g$ flips - at $g \approx 3.77$ percent. This threshold offers one possible explanation why wealth-income ratios are rising in most major economies during the twenty first century, irrespective of per-capita income levels. The two most populated countries in the world entered high economic growth phases in their development trajectory at the same time as rich countries matured into their low growth phase, thus putting both sets into either ends of the growth spectrum, but the same trajectory vis-a-vis wealth-income ratios.

\section{Conclusion}

This paper presented the first evidence on how and why wealth-income ratios evolved in India over the long run. In the first half of the twentieth century, India was very underdeveloped and low growth created an environment where wealthincome ratios could fluctuate quite a lot. Over time, capital filled into the share of wealth and as growth took off, wealth-income ratios increased. India's wealth accumulation in recent decades is best explained as an outcome of its ongoing transition from an economy where traditional economic activity, and land, were dominant, to one where organized sector is expanding and driving capital accumulation.

On the basis of trends presented here, I argued that the relationship between wealth-income ratios and economic growth is U-shaped. This hypothesis bears out in inter-temporal data for India as well as cross-country evidence for recent decades, thus explaining why wealth-income ratios have risen in several major countries during the twenty first century. Per-capita income has little to do with this; on one end is the imperialism of asset price compounding and low growth, 
on the other end is capital accumulation and economic growth. Obviously, this relationship was tested based on limited data and using basic quantitative tools. But it opens up an interesting set of questions. In particular, the dynamics of the wealth-income ratios around the turning point can be better understood by assembling more detailed cross-country data, or studying an economy that undergoes the reverse transition (from high to low growth), thus offering interesting avenues for future research.

\section{Appendices}

An appendix is available online at the link:

https://www.dropbox.com/s/2k4fqgkqv85lufg/App1.pdf?dl=0 


\section{References}

Abbas, S. A., N. Belhocine, A. El-Ganainy, And M. Horton (2011): "Historical patterns and dynamics of public debt-evidence from a new database," IMF Economic Review, 59, 717-742.

Acemoglu, D., S. Johnson, And J. A. Robinson (2002): "Reversal of fortune: Geography and institutions in the making of the modern world income distribution," The Quarterly journal of economics, 117, 1231-1294.

ACHARYA, S. (2005): “Thirty years of tax reform in India," Economic and Political Weekly, 40, 2061-2070.

Ahluwalia, M. S. (2002): "Economic reforms in India since 1991: Has gradualism worked?" Journal of Economic perspectives, 16, 67-88.

Allen, F., R. Chakrabarti, S. De, J. Qian, And M. Qian (2006): Financing firms in India, The World Bank.

Allen, R. C. (2020): "Poverty and the labor market: today and yesterday," Annual review of economics, 12, 107-134.

Alvaredo, F., A. Bergeron, And G. CASSAN (2017): "Income concentration in British India, 1885-1946," Journal of Development Economics, 127, 459-469.

ANAND, I., R. KUMAR, ET AL. (2022): “The sky and the stratosphere: concentrated wealth in India during the 'lost decade'," Tech. rep., Center for Open Science. 
Artola, M., L. Estévez, And C. Martínez-Toledano (2021): "Wealth in Spain, 1900-2014. A country of two lands," The Economic Journal, 131.

ATKInson, F. J. (1902): “A statistical review of the income and wealth of British India," Journal of the Royal Statistical Society, 209-283.

BAdArinza, C., V. BAlasubramaniam, And T. RAmadorai (2017): “The Indian Household Savings Landscape," India Policy Forum.

BLyn, G. (1966): Agricultural trends in India, 1891-1947: output, availability, and productivity., Philadelphia: Univ. Pa Press.

Broadberry, S., J. Custodis, And B. Gupta (2015): "India and the great divergence: An Anglo-Indian comparison of GDP per capita, 1600-1871," Explorations in Economic History, 55, 58-75.

Chancel, L. And T. PiketTy (2019): “Indian Income Inequality, 1922-2015: From British Raj to Billionaire Raj?” Review of Income and Wealth, 65, S33S62.

Chancel, L., T. Piketty, E. SAez, And G. Zucman (2018): World Inequality Report 2018, Cambridge: Belknap Press.

Charalampidis, N. (2018): "The National Wealth-Income Ratio in Greece, 1974-2013," Review of Income and Wealth, 64, 83-104.

Chauvin, J. P., E. Glaeser, Y. MA, AND K. Tobio (2017): "What is different about urbanization in rich and poor countries? Cities in Brazil, China, India and the United States," Journal of Urban Economics, 98, 17-49. 
Eichengreen, B. AND P. Gupta (2011): “The Service Sector as India's Road to Economic Growth?" in India Policy Forum 2010-11: Volume 7, SAGE Publications India, vol. 7, 1.

GHANi, S. E., W. KerR, AND S. D. O'CONnEll (2013): “The exceptional persistence of India's unorganized sector," World Bank Policy Research Working Paper.

Goldsmith, R. W. (1983): The Financial Development of India, 1860-1977, Oxford University Press.

GuHA, S. (1991): "Mortality decline in early twentieth century India: A preliminary enquiry," The Indian Economic \& Social History Review, 28, 371-391.

Heston, A. (1983): National income, Cambridge University Press, Cambridge, vol. 2, 463-532.

Khanna, T. AND K. PALEPU (2005): “The evolution of concentrated ownership in India: broad patterns and a history of the Indian software industry," in $A$ history of corporate governance around the world: Family business groups to professional managers, University of Chicago press, 283-324.

KUMAR, R. (2020): “Top Indian wealth shares and inheritances 1966-1985," Cliometrica, 14, 551-580.

LAmbA, R. AND A. Subramanian (2020): "Dynamism with incommensurate development: The distinctive Indian model," Journal of Economic Perspectives, 34, 3-30. 
LAne, P. R. And G. M. Milesi-Ferretti (2007): “The external wealth of nations mark II: Revised and extended estimates of foreign assets and liabilities, 1970-2004," Journal of international Economics, 73, 223-250.

LeE, W. And Y. Yoon (2017): “Capital in South Korea: 1966-2014,” Social Choice and Welfare, 49, 671-708.

LEWIS, W. A. (1954): "Economic Development with Unlimited Supplies of Labour," The Manchester School, 22, 139-191.

MAdDison, A. (2001): The world economy: a millennial perspective, Economic Co-orperation and Development (OECD).

Madsen, J. B. (2019): "Wealth and inequality over eight centuries of British capitalism," Journal of Development Economics.

MukHerJeE, M. (1964): "An estimate of the reproducible tangible wealth of India in March 1961," Economic Affairs (Calcutta), 9, 25.

MukHerjee, M. AND N. SASTRY (1959): “An Estimate of the Tangible Wealth of India," Review of Income and Wealth, 8, 365-387.

NAGARAJ, R., T. SRINIVASAN, ET AL. (2016): "Measuring India's GDP growth: Unpacking the analytics \& data issues behind a controversy that refuses to go away," in India Policy Forum, National Council for Applied Economic Research New Delhi, vol. 13, 73-128.

Novokmet, F., T. Piketty, And G. Zucman (2018): "From Soviets to oligarchs: inequality and property in Russia 1905-2016," The Journal of Economic Inequality, 16, 189-223. 
PiketTy, T. (2014): Capital in the twenty first century, Harvard University Press.

Piketty, T., L. YAng, AND G. Zucman (2017): "Capital Accumulation, Private Property and Rising Inequality in China, 1978-2015,”.

PikeTtY, T. AND G. ZuCMAN (2014): "Capital is back: Wealth-income ratios in rich countries 1700-2010," The Quarterly Journal of Economics, 129, 12551310 .

Rodrik, D. AND A. Subramanian (2005): "From "Hindu growth" to productivity surge: The mystery of the Indian growth transition," IMF Staff Papers, $52,193-228$.

Rothermund, D. (1980): “The impact of the Great Depression on India in the 1930s," in Proceedings of the Indian History Congress, JSTOR, vol. 41, 657669.

RoY, B. (1967): “Capital formation in India: 1901-51," Economic and Political Weekly, 807-811.

RoY, T. (2002): "Economic History and Modern India: Redefining the Link," Journal of Economic Perspectives, 16, 109-130.

— (2006): "Roots of agrarian crisis in interwar India: Retrieving a narrative," Economic and Political Weekly, 5389-5400.

_ (2016): "The British Empire And The Economic Development Of India (1858-1947)," Revista de Historia Economica-Journal of Iberian and Latin American Economic History, 34, 209-236. 
Sivasubramonian, S. (2000): The national income of India in the twentieth century, Oxford University Press, USA.

Subramanian, A. (2019): “India's GDP mis-estimation: Likelihood, magnitudes, mechanisms, and implications," CID Working Paper Series.

Tombinson, B. R. (2013): The economy of modern India: from 1860 to the twenty-first century, vol. 3, Cambridge University Press.

VAN TREeCK, K. (2020): "Measuring the labor income share of developing countries: Lessons from social accounting matrices," Review of Income and Wealth, $66,584-612$.

WALDENSTRÖM, D. (2017): "Wealth-income ratios in a small, developing economy: Sweden, 1810-2014," The Journal of Economic History, 77, 285-313. (2021): "Wealth and History: An Update," . 